Asian J. Med. Biol. Res. 2020, 6 (2), 204-211; doi: 10.3329/ajmbr.v6i2.48051

\author{
Asian Journal of \\ Medical and Biological Research \\ ISSN 2411-4472 (Print) 2412-5571 (Online) \\ www.ebupress.com/journal/ajmbr
}

\title{
Article \\ Sensor based calibration study for in-season nitrogen management of winter wheat in Turkey
}

\author{
Erdinc SAVASLI ${ }^{1 *}$, Oguz ONDER ${ }^{1}$, Cemal CEKIC ${ }^{1}$, Hasan Mufit KALAYCI ${ }^{1}$, Ramis DAYIOGLU ${ }^{1}$, Yasar \\ KARADUMAN $^{1}$, Fatma GOKMEN ${ }^{2}$, Nesim DURSUN ${ }^{2}$ and Sait GEZGIN ${ }^{2}$ \\ ${ }^{1}$ Transitional Zone Agricultural Research Institute, Eskisehir / Turkey \\ ${ }^{2}$ Selçuk University, Faculty of Agriculture, Department of Soil Science and Plant Nutrition, 42075, Konya / \\ Turkey
}

*Corresponding author: Erdinc SAVASLI, Transitional Zone Agricultural Research Institute, Eskisehir / Turkey. Phone: +905362687055; E-mail: esavasli26@gmail.com

Received: 27 April 2020/Accepted: 03 June 2020/ Published: 30 June 2020

\begin{abstract}
The aims of this study were to compare the responses of four winter wheat cultivars to nitrogen fertilization with vegetation indices calculated using spectral reflection (GreenSeeker hand-held sensor) and to estimate in-season yield (INSEY) using the vegetation indices. The field experiment was conducted at Transitional Zone Agricultural Research Institute of Eskisehir province, Turkey in 2007-2008, 2008-2009 and 2009-2010 growing seasons. The experimental layout was a 2 factor factorial in the randomized complete block design. Nitrogen rates were $0,40,80,120,160$ and $200 \mathrm{~kg} \mathrm{~N} \mathrm{ha}^{-1}$. Vegetation Index (NDVI) was obtained at growth stages of Zadoks 24 (tillering stage), Zadoks stage 30 (stem elongation), Zadoks stage 31 (the first node is visible) and Zadoks stage 32 (the second node is visible). The results revealed that Zadoks stage 30 was the most realistic reading time. NDVI had the advantage of providing information on biomass, in addition to nitrogen nutrition status of crops, enabling in-season yield estimation possible. Therefore, NDVI based calibration equations were preferred for testing in the fields of actual farmers for the last year of study. A comparison of the system with traditional farmer applications indicated that yield estimation obtained by the new system was quite similar yields with $13.2 \mathrm{~kg} \mathrm{ha}^{-1}$ less $\mathrm{N}$ in the spring (ZD 3.0), showing its economically promising value.
\end{abstract}

Keywords: wheat; vegetation index; NDVI; Greenseeker; INSEY

\footnotetext{
1. Introduction

Nitrogen (N) is one of the essential nutrients for plant growth (Baral et al., 2015). The use of optical sensors to detect $\mathrm{N}$ deficiencies and determine in-season fertilizer recommendations have recently increased (Bushong $e t$ al., 2018). The $\mathrm{N}$ recommendations for the irrigated wheat area lead to low $\mathrm{N}$-use efficiency due to field-to-field variability in soil $\mathrm{N}$ supply and seasonal variability in yield (Bijay-Singh et al., 2011). Expected yields could be inconsistent from field-to-field and year-to-year depending on factors that are difficult to predict prior for fertilizer applications. A positive correlation was observed between grain yield and NDVI (Aparicio et al., 2000) and between NDVI and N use efficiency (NUE) (Naser, 2012). Sensor-guided fertilizer N applications resulted in high yield levels and high $\mathrm{N}$ use efficiency (NUE) values (Bijay-Singh et al., 2010). In this study, the investigated the performance of optical sensors in large field trials, to predict yield and biomass characteristics (Christoph et al., 2018). Farmers use sensors to estimate crop biomass production and yield potential, and make fertilizer recommendations (Olga, 2015).

Raun et al. (2002) have been reported recent developments in the adjustment of $\mathrm{N}$ fertilizer recommendations using in-season yield estimates (INSEY). The INSEY index is calculated by dividing the NDVI value by the number of days between sowing and sensing. Then the response index (RI) can be calculated (Mullen et al.,
} 
2003). Flowers et al. (2003) reported a strong relationship between NDVI and N uptake and plant $\mathrm{N}$ concentration in wheat.

The method basically composed of three stages: i.) Establishing calibration equations between INSEY values and actual yields attained ii.) Setting validation trials on farmer fields in the target region to refine these equations considering the deviations from experimental results and iii.) establishing N-rich strips on each individual farmer field to compare INSEY values and calculate RI values from the differences between N-rich strips and application of farmer to provide the recommendation for that individual field and the season (Raun $e t$ al., 2005).

The experiment presented in this paper is the first application of the calibration stage of this new method in Turkey. The objective of this study was to determine the wheat yield potential estimated using an in-season estimation of NDVI.

\section{Materials and Methods}

Calibration experiments were conducted for 3 years (2007-2008, 2008-2009 and 2009-2010) on experimental fields of Transitional Zone Agricultural Research Institute in Turkey. Four registered bread wheat cultivars (Alpu2001, Katea 1, 1 Bezostaya1 and Konya2002) adapted to the irrigated conditions of the region were used in the experiments. The responses of these cultivars to $\mathrm{N}$ fertilization were compared with vegetation indices based on spectral reflection and calculated In-Season Estimated Yield values. However, the results were presented as the average of the cultivars since limited data for individual cultivars cause deviations. Nitrogen rates of $0,40,80,120,160$ and $200 \mathrm{~kg} \mathrm{ha}^{-1}$ were used. Whole nitrogen was applied just before planting as urea or ammonium nitrate form. Sowing time applied Nitrogen treatments to create a variation for NDVI read. The experimental layout was factorial in randomized complete block design, the seeding rate of the experimental treatments was 450 kernel $\mathrm{m}^{-2}$.

Monthly precipitations for the experimental years of the research institute were provided in Table 1.

The experimental soils formed over deep alluvial sediments. The soils were high clay content (50.2\%), low organic matter $(1.13 \%)$, medium in lime content and slightly alkaline character $(\mathrm{pH}=7.83) . \mathrm{The}^{\mathrm{NO}} \mathrm{O}_{3}$ and $\mathrm{NH}_{4}+\mathrm{NO}_{3} \mathrm{~N}$ analyses were performed with two different methods recommended by Bremner (1965) (Table 2).

The GreenSeeker ${ }^{\mathrm{TM}}$ (NTech Industries, Inc., Ukiah, CA Model 505) hand-held sensor was used to compute the Normalized Difference Vegetation Index (NDVI). The reading dates were determined according to Zadoks scale (Zadoks et al., 1974) as Zadoks stage 24 (tillering stage with 4 tillers), Zadoks stage 30 (pseudo stem elongation), Zadoks stage 31 (onset of stem elongation when the first node is visible) and Zadoks stage 32 (onset of stem elongation when the second node is visible). In-Season Estimated of Yield (INSEY) was calculated as described by Raun et al. (2002). The INSEY was calculated by dividing the NDVI data by the number of growing degree days $(\mathrm{GDD})>0\left(\mathrm{GDD}=(\mathrm{Tmin}+\mathrm{Tmax}) / 2-4.4{ }^{\circ} \mathrm{C}\right.$, where $\mathrm{Tmin}$ and $\mathrm{Tmax}$ represent daily ambient low and high temperatures) from planting to sensing as proposed by Raun et al. (2002). Response Index (RI) values for NDVI and grain yields were calculated according to Raun et al. (2005).

The N Rich Strip should be applied at before planting for winter wheat. All the $\mathrm{N}$ in the $\mathrm{N}$ rate experiment was applied just before planting time as urea or ammonium nitrate and incorporated to the planting operation. The $\mathrm{N}$ rich strip in wheat field was established by applying $200 \mathrm{~kg} \mathrm{~N} \mathrm{ha}^{-1}$ to a strip of $4 \mathrm{~m}$ wide and about $50 \mathrm{~m}$ long $\left(200 \mathrm{~m}^{2}\right)$. Spring season $\mathrm{N}$ was applied based on NDVI value depending on $\mathrm{N}$ rate calculated in calibration experiments. The NDVI was calculated as follow-

$\mathrm{NDVI}=(\mathrm{P}-\mathrm{NIR}) /(\mathrm{P}+\mathrm{NIR})$.

Where NDVI is the reflectance of red $(660 \mathrm{~nm})$ and NIR $(770 \mathrm{~nm})$ and NDVI values ranged from 0.00 to 0.99 .

\subsection{Statistical analysis}

Fisher's protected LSD post-hoc analyses were performed on significant (alpha D 0.10) main and interactive treatment effects. Calibration equations were developed using JMP 13.0.0 (SAS Institute Inc. Cary, NC, USA) statistics package program.

\section{Results and Discussion}

\subsection{Grain yield and NDVI}

Grain yields obtained in the experiments were given in Table 3. As can be seen in Table 3, applications of different rates of nitrogen increased grain yield in every 3 years. There were statistically significant differences between genotypes for the grain yield all the years.

Different Nitrogen rate applications were significant increases in wheat grain yields in all of the experiments. The effect of nitrogen rates on the grain yield is given in Table 3. As it is seen in Table 3, that four Genotype 
have increased the grain yield on three locations. But the yields were a bit lower in the third year as compared to first two years. Increasing nitrogen rates have increased the grain yields according to control treatment.

Walsh et al. (2018) has also found out increased grain yields of wheat when $\mathrm{N}$ fertilizers are applied at sowing time. The difference in yields of three locations might be due to the fact of different amount of precipitation, precrop and of different physical and chemical properties of the locations. NDVI Sensor system is a promising approach for predicting Wheat yield. Yield prediction is important in the development of algorithms for sensorbased Nitrogen management (Tagarakis and Ketterings, 2017).

The NDVI and Response Index (RI) values were shown in Figure 1 The NDVI values obtained at growth stages of Zadoks stage 24 (tillering stage with 4 tillers), Zadoks stage 30 (pseudo stem elongation stage) and Zadoks stage 31 (stem elongation stage with 1 node) and Zadoks stage 32 (stem elongation stage with 2 nodes) (Zadoks et al., 1974) were presented in Table 4.

The differences in crop establishment among three years were also reflected in NDVI readings (Figure 1). Olga et al. (2018) have also reported a significant positive correlation between NDVI values and preplant $\mathrm{N}$ application rates. The lowest NDVI values obtained at Zadoks stage 24 in the third year were resulted not only from weaker early crop growth but also from the insufficient ground cover (Figure 1). Soil background has a significant effect on canopy reflectance, especially at low biomass rate (Huete et al., 1985). Heilman and Kress (1987) showed that the effect of soil background on irradiance is significant when total aboveground biomass is less than 50\% (Heilman and Kress, 1987). In contrast, Lukina et al. (2000) stated that soil reflectance was not an important factor when total aboveground biomass was more than $40 \%$.

The RINDVI values at Zadoks 30 stage were higher, however, RINDVI values reduced Zadoks 31 and 32 stages became closer to those obtained at Zadoks 24 stage. The main objective of the study was to determine the growth stage where RINDVI is the most representative of RIYIELD rather than the highest value of RINDVI per se. Therefore, mean RIYIELD values of 3 experiments and correlation coefficients between RINDVI and RIYIELD were given in Table 5.

The RI YIELD values of Alpu2001 and Konya, recent breed cultivars with high yield potentials were higher than the other two varieties (Table 5). The results confirmed that higher $\mathrm{RI}_{\text {YIELD }}$ values are related to higher yields. High correlation coefficients obtained for all growth stages indicate the greater importance of ground cover than the stage itself. The early growth stages such as Zadoks 24 can also be used for recommendations, provided that there is enough ground cover (giving at least 0.30-0.40 NDVI values).

Calibration equations: Calibration equations for irrigated winter wheat in 3 different years as averaged over 4 cultivars. The algorithms were generally based on in-season estimated yield (INSEY). The INSEY was determined by dividing the sensor NDVI readings by the growing degree days.

ZADOKS 24: YIELD $\left(\mathrm{kg} \mathrm{ha}^{-1}\right)=-1489.5+808017.9\left(\right.$ INSEY) $\left(\mathrm{R}^{2}=0.98^{* *}, \mathrm{n}=6\right)(1)$

ZADOKS 30: YIELD $\left(\mathrm{kg} \mathrm{ha}^{-1}\right)=192.2+659592.3\left(\right.$ INSEY) $\left(\mathrm{R}^{2}=0.99 * *, \mathrm{n}=6\right)$

ZADOKS 31: YIELD $\left(\mathrm{kg} \mathrm{ha}^{-1}\right)=-1055.9+876962.7(\operatorname{INSEY})\left(\mathrm{R}^{2}=0.99 * *, \mathrm{n}=6\right)(3)$

ZADOKS 32: YIELD $\left(\mathrm{kg} \mathrm{ha}^{-1}\right)=-1324.9+100745.0($ INSEY $)\left(\mathrm{R}^{2}=0.99 * *, \mathrm{n}=6\right)(4)$

In contrast to the others who used exponential equations, the linear relations were obtained for all seasons and cultivars (Figure 2). Exponential transformations (Central Anatolia of Turkey) did not make any significant contribution to the determination coefficients. The differences between ecologies of Central Anatolia and Oklahoma and Mexico might cause to the differences. The results revealed that calibration equations are site specific and the equations obtained in this study can be used for the farmer recommendations in Central Anatolia of Turkey. The readings for all growth stages resulted in significantly high determination coefficients $(\mathrm{p}<0.01)$, when averaged over years and cultivars. The differences in determination coefficients among growth stages were not significant, thus Zadoks 30 was accepted as the most suitable growth stage for applications in farmer fields. The $\mathrm{N}$ applied at Zadoks stage 30 was reported to have the highest effect on the growth of winter wheat (Baethgen and Alley, 1989). Melaj et al. (2003) reached the same conclusion, explaining that wheat reaches to maximum growth rate at this stage. However, Weisz et al. (2001) reported that some of the $\mathrm{N}$ should be used earlier than Zadoks stage 30 when early growth and tillering of wheat is not sufficient. Considering the difficulties and risks of using a tractor in the field after this stage, Zadoks 30 was considered as the most suitable time to apply $\mathrm{N}$ for irrigated winter wheat. Olga et al. (2018) stated that $\mathrm{N}$ fertilizer rates recommended by the USA/Canada/Mexico Algorithm were not appropriate for grain yield optimization. The recommendation brought by Olga et al. (2018) puts forward a question of whether there is a need for two separate algorithms, one developed for dryland spring wheat and the other for irrigated spring wheat production system.

In the six experiments carried out at in Eskisehir during 2011-2012 growing seasons, $200 \mathrm{~kg} \mathrm{~N}^{-1}$ was applied to the rich strips. The response indices RINDVI and RIHarvest were calculated (Mullen et al., 2003; Johnson and Raun, 2003). NDVI was obtained from the sensor measurements. 


\subsection{Farmer applications}

The system works in the farmers field by establishing an $\mathrm{N}$-rich strip (to guarantee that there will be no $\mathrm{N}$ deficiency in that area). The new system was compared with traditional farmer applications, based on the average of 6 farmer fields. The new system provided similar yields with $13.2 \mathrm{~kg} \mathrm{ha}^{-1}$ less $\mathrm{N}$ in the spring (ZD 3.0), showing its economically promising value (Table 6).

The results of validation trials showed that farmers were able to save $69 \mathrm{~kg} \mathrm{~N} \mathrm{ha}^{-1}$, without any yield reduction (Ortiz-Monasterio and Raun, 2007). The use of crop sensors has been shown to produce savings of $\$ 10$ to $\$ 20$ per acre (Andrews, 2011). GreenSeeker sensors can improve $\mathrm{N}$ use efficiency with significant increase in net profits (Li et al., 2009; Tubaña et al., 2008). The $\mathrm{N}$ use efficiency could be increased at a rate of $15 \%$ with sensor-based variable rate $\mathrm{N}$ fertilization (Raun et al., 2002).

Table 1. Monthly precipitation of the experimental site at the Institute during 2007-2010 growing seasons (mm).

\begin{tabular}{l|l|l|l|l|l|l|l|l|l|l|l|l|l}
\hline Years & Sep. & Oct & Nov & Dec & Jan & Feb & Marc & April & May & June & July & Aug. & $\begin{array}{l}\text { Annual Total } \\
(\mathbf{m m})\end{array}$ \\
\hline Long-Term & 14.7 & 25.2 & 30.6 & 45.6 & 38.4 & 32.6 & 33.3 & 35.0 & 42.1 & 29.3 & 13.8 & 6.5 & 347 \\
$2007-08$ & 0.0 & 19.2 & 92.4 & 49.9 & 15.7 & 1.0 & 42.4 & 38.5 & 11.7 & 9.3 & 0.0 & 5.5 & 286 \\
$2008-09$ & 30.7 & 6.4 & 49.6 & 34.5 & 66.3 & 82.0 & 40.9 & 28.0 & 15.4 & 10.2 & 19.4 & 2.0 & 385 \\
$2009-10$ & 7.1 & 9.0 & 29.5 & 65.1 & 36.0 & 42.8 & 32.6 & 23.9 & 20.7 & 79.0 & 7.4 & 0.9 & 354 \\
\hline
\end{tabular}

Table 2. Soil characteristics of experimental sites ( 0 to $30 \mathrm{~cm}$ soil layer).

\begin{tabular}{l|l|l|ll}
\hline Characteristics & Unit & $\begin{array}{l}\mathbf{2 0 0 8} \\
\text { INST. }\end{array}$ & $\begin{array}{l}\mathbf{2 0 0 9} \\
\text { INST. }\end{array}$ & $\begin{array}{l}\mathbf{2 0 1 0} \\
\text { INST. }\end{array}$ \\
\hline Texture & & Clay & Clay & Clay \\
pH (1:2.5 Soil:Water) & & 7.83 & 7.52 & 7.54 \\
EC (Salt) (1:5 Soil:Water) & $\left(\mu \mathrm{S} \mathrm{cm}^{-1}\right)$ & 156 & 140 & 230 \\
$\mathrm{CaCO}_{3}$ (Lime) & $(\%)$ & 10.9 & 9.6 & 8.0 \\
Organic Matter & $(\%)$ & 1.13 & 1.1 & 1.77 \\
Phosphorus & $\left(\mathrm{mg} \mathrm{kg}^{-1}\right)$ & 33.3 & 32.1 & 27.8 \\
Potassium & $\left(\mathrm{mg} \mathrm{kg}^{-1}\right)$ & 671 & 666 & 493 \\
Phenoldisulphonic Acid ${\mathrm{Method}\left(\mathrm{NO}_{3}\right)}_{\mathrm{KCl} \text { Extraction Method }\left(\mathrm{NH}_{4}^{+}, \mathrm{NO}_{3}\right)}^{\left(\mathrm{mg} \mathrm{kg}^{-1}\right)}$ & 2.1 & 3.30 & 0.84 \\
\hline
\end{tabular}

Table 3. Effects of Nitrogen fertilization on grain yields of irrigated winter wheat in 3 different years as averaged over 4 cultivars.

\begin{tabular}{|c|c|c|c|c|c|}
\hline N RATE & & Grain & $1\left(\mathrm{~kg} \mathrm{ha}^{-1}\right) 20$ & & \\
\hline$\left(\mathrm{kg} \mathrm{N} \mathrm{ha}^{-1}\right)$ & ALPU2001 & \begin{tabular}{|l|} 
BEZOSTAY1 \\
\end{tabular} & KATE-A1 & KONYA & Mean \\
\hline 0 & 5196 & 4053 & 4713 & 4438 & $4600 \mathrm{c}$ \\
\hline 40 & 6830 & 4750 & 5070 & 5150 & $5450 \mathrm{~b}$ \\
\hline 80 & 7770 & 4830 & 5320 & 4759 & $5670 \mathrm{~b}$ \\
\hline 120 & 8068 & 4869 & 5969 & 5933 & $6210 \mathrm{a}$ \\
\hline 160 & 8338 & 4859 & 5840 & 6085 & $6280 \mathrm{a}$ \\
\hline 200 & 7981 & 4710 & 5544 & 6526 & $6190 \mathrm{a}$ \\
\hline Mean & $7364 \mathrm{a}$ & $4678 \mathrm{c}$ & $5409 \mathrm{~b}$ & $5482 \mathrm{~b}$ & \\
\hline $\mathrm{CV}(\%): 11.5$ & $(0.05)$ Genoty & Lsd (0.05) Nitroge & $5 * * \quad \operatorname{Lsd}(0$. & enotype*Nit & $50 *$ \\
\hline N RATE & & Grain & $\left(\mathrm{kg} \mathrm{ha}^{-1}\right) 20$ & & \\
\hline$\left(\mathrm{kg} \mathrm{N} \mathrm{ha}^{-1}\right)$ & ALPU2001 & \begin{tabular}{|l|} 
BEZOSTAYA1 \\
\end{tabular} & KATE-A1 & KONYA & Mean \\
\hline 0 & 6600 & 5138 & 6359 & 5264 & $5840 \mathrm{~b}$ \\
\hline 40 & 6810 & 5060 & 6930 & 6680 & $6370 \mathrm{ab}$ \\
\hline 80 & 7749 & 5482 & 6639 & 6729 & $6650 \mathrm{a}$ \\
\hline 120 & 8310 & 5610 & 6800 & 6920 & $6910 \mathrm{a}$ \\
\hline 160 & 7150 & 5320 & 7118 & 7090 & $6670 \mathrm{a}$ \\
\hline 200 & 7370 & 4300 & 5463 & 5507 & $5660 \mathrm{~b}$ \\
\hline MEAN & $7332 a$ & $5152 \mathrm{c}$ & $6552 \mathrm{~b}$ & $6365 \mathrm{~b}$ & \\
\hline $\mathrm{CV}(\%): 13.1$ & Lsd (0.05) Gen & * Lsd (0.05) Nitro & $610^{*}$ & Senotype*1 & $1025^{*}$ \\
\hline N RATE & & Grain & $\left(\mathrm{kg} \mathrm{ha}^{-1}\right) 20$ & & \\
\hline$\left(\mathrm{kgNha}^{-1}\right)$ & ALPU2001 & \begin{tabular}{|l|} 
BEZSTAYA1 \\
\end{tabular} & KATE-A1 & KONYA & Mean \\
\hline 0 & 1610 & 1750 & 2410 & 1750 & $1880 \mathrm{e}$ \\
\hline
\end{tabular}




\begin{tabular}{llllll}
40 & 3205 & 2889 & 3820 & 2965 & $3220 \mathrm{~d}$ \\
80 & 4830 & 4340 & 4230 & 4599 & $4500 \mathrm{c}$ \\
120 & 5793 & 5526 & 5100 & 5339 & $5440 \mathrm{~b}$ \\
160 & 6643 & 5419 & 5472 & 6025 & $5890 \mathrm{a}$ \\
200 & 7309 & 5374 & 5403 & 6675 & $6190 \mathrm{a}$ \\
\hline Mean & $4898 \mathrm{a}$ & $4216 \mathrm{c}$ & $4406 \mathrm{bc}$ & $459 \mathrm{~b}$ \\
\hline CV (\%):12.1 Lsd (0.05)Genotype: $316^{*}$ Lsd (0.05) Nitrogen :387** Lsd (0.05) Genotype*Nitrogen: $710^{*}$
\end{tabular}

Means with the same the letters are statistically non-significant, ** Significant at $\mathrm{p}<0.01$ level, * Significant at $\mathrm{p}<0.05$ level by Fisher's Lsd, NS: Non-significant

Table 4. The Effects of Nitrogen fertilization on NDVI values obtained at 4 different growth stages in 3 different years as averaged over 4 cultivars.

\begin{tabular}{|c|c|c|c|c|c|}
\hline \multirow{2}{*}{$\begin{array}{l}\text { N RATE } \\
\left(\text { kg N ha }^{-1}\right)\end{array}$} & \multicolumn{5}{|c|}{ NDVI } \\
\hline & \begin{tabular}{|l|} 
Zadoks 24 \\
\end{tabular} & Zadoks 30 & \multicolumn{2}{|l|}{ Zadoks 31} & Zadoks 32 \\
\hline 0 & 0.538 & 0.524 & 0.570 & \multicolumn{2}{|c|}{0.587} \\
\hline 40 & 0.656 & 0.664 & 0.678 & \multicolumn{2}{|c|}{0.673} \\
\hline 80 & 0.745 & 0.765 & 0.760 & \multicolumn{2}{|c|}{0.754} \\
\hline 120 & 0.772 & 0.813 & 0.805 & \multicolumn{2}{|c|}{0.803} \\
\hline 160 & 0.788 & 0.836 & 0.828 & \multicolumn{2}{|c|}{0.824} \\
\hline 200 & 0.795 & 0.849 & 0.843 & \multicolumn{2}{|c|}{0.844} \\
\hline Mean & 0.716 & 0.742 & 0.747 & \multicolumn{2}{|c|}{0.747} \\
\hline$\overline{L s d}(0.05)$ & $0.026 * *$ & $0.020 * *$ & $0.018 * *$ & \multicolumn{2}{|c|}{$0.016^{* *}$} \\
\hline $\mathrm{CV}(\%)$ & 9.3 & 6.7 & 5.9 & \multicolumn{2}{|c|}{5.5} \\
\hline \multirow{2}{*}{$\begin{array}{l}\text { N RATE } \\
\left(\operatorname{kg~N~ha~}^{-1}\right)\end{array}$} & \multicolumn{5}{|c|}{$\mathbf{R I}_{\text {NDVI }}$} \\
\hline & \begin{tabular}{|l|} 
Zadoks 24 \\
\end{tabular} & Zadoks 30 & Zadoks 31 & Zadoks 3 & Mean \\
\hline 0 & 1.00 & 1.00 & 1.00 & 1.00 & 1.00 \\
\hline 40 & 1.39 & 1.59 & 1.37 & 1.31 & 1.42 \\
\hline 80 & 1.68 & 2.04 & 1.67 & 1.61 & 1.75 \\
\hline 120 & 1.79 & 2.29 & 1.85 & 1.80 & 1.93 \\
\hline 160 & 1.82 & 2.38 & 1.94 & 1.89 & 2.00 \\
\hline 200 & 1.87 & 2.42 & 1.99 & 1.95 & 2.06 \\
\hline Mean & 1.59 & 1.95 & 1.64 & 1.59 & 1.69 \\
\hline
\end{tabular}

Means with the same the letters are statistically non-significant, ** Significant at $\mathrm{p}<0.01$ level, * Significant at $\mathrm{p}<0.05$ level by Fisher's Lsd, NS: Non-significant

Table 5. Correlation coefficients between $R I_{Y I E L D}$ and $R_{\text {NDVI }}$ values obtained at different growth stages at the irrigated calibration study $(n=18)$.

\begin{tabular}{|c|c|c|c|c|c|}
\hline \multirow{2}{*}{$\begin{array}{l}\text { N RATE } \\
\left(\mathrm{kg} \mathbf{N} \mathrm{ha}^{-1}\right)\end{array}$} & \multicolumn{5}{|c|}{$\mathbf{R I}_{\text {YIEID }}$} \\
\hline & ALPU2001 & BEZOSTAYA1 & KATE-A1 & KONYA & Mean \\
\hline 0 & 1.00 & 1.00 & 1.00 & 1.00 & 1.00 \\
\hline 40 & 1.32 & 1.21 & 1.22 & 1.29 & 1.26 \\
\hline 80 & 1.56 & 1.38 & 1.19 & 1.45 & 1.40 \\
\hline 120 & 1.70 & 1.51 & 1.36 & 1.64 & 1.55 \\
\hline 160 & 1.76 & 1.48 & 1.35 & 1.72 & 1.58 \\
\hline 200 & 1.76 & 1.45 & 1.40 & 1.78 & 1.60 \\
\hline Mean & 1.52 & 1.34 & 1.25 & 1.48 & 1.40 \\
\hline \multirow{2}{*}{$\begin{array}{l}\text { GROWTH } \\
\text { STAGE }\end{array}$} & \multicolumn{5}{|c|}{ CORRELATION COEFFICIENTS } \\
\hline & ALPU2001 & BEZOSTAYA1 & KATE-A1 & KONYA & Mean \\
\hline Zadoks 24 & $0.98 * *$ & $0.99 * *$ & $0.97 * *$ & $0.98 * *$ & 0.98 \\
\hline Zadoks 30 & $0.98 * *$ & $0.99 * *$ & $0.98 * *$ & $0.99 * *$ & 0.99 \\
\hline Zadoks 31 & $0.99 * *$ & $0.99 * *$ & $0.98 * *$ & $0.99 * *$ & 0.99 \\
\hline Zadoks 32 & $0.99 * *$ & $0.99 * *$ & $0.97 * *$ & $0.99 * *$ & 0.99 \\
\hline Mean & 0.99 & 0.99 & 0.98 & $0.99 * *$ & 0.99 \\
\hline
\end{tabular}

** Significant at $\mathrm{p}<0.01$ level, $*$ Significant at $\mathrm{p}<0.05$, NS: Non-significant 
Asian J. Med. Biol. Res. 2020, 6 (2)

Table 6. Effect of Nitrogen fertilization on grain yield of irrigated winter wheat in 6 farmer fields.

\begin{tabular}{lllllll}
\hline Genotype & Previous Plant & Field & \multicolumn{2}{c}{ Applied Nitrogen } & \multicolumn{2}{c}{ Grain Yield } \\
\cline { 3 - 6 } & & & Farmer & Sensor & Farmer & Sensor \\
\hline Sönmez2001 & Beans & 1 & 120 & 77 & 7780 & 6950 \\
Katea1 & Corn & 2 & 120 & 133 & 7240 & 8050 \\
Konya & Sugar Beet & 3 & 120 & 98 & 6570 & 7310 \\
Bezostaya1 & Corn & 4 & 120 & 130 & 3220 & 4270 \\
Konya & Corn & 5 & 120 & 123 & 4610 & 4360 \\
Harmankaya99 & Potato & 6 & 120 & 80 & 7770 & 8470 \\
\hline & & Mean & 120.0 & 106.8 & 6198 & 6568 \\
\cline { 3 - 6 } & & Difference & 13.2 & & 370 & \\
\hline
\end{tabular}

Note: 6 farmer fields demonstrations aren't replicates.
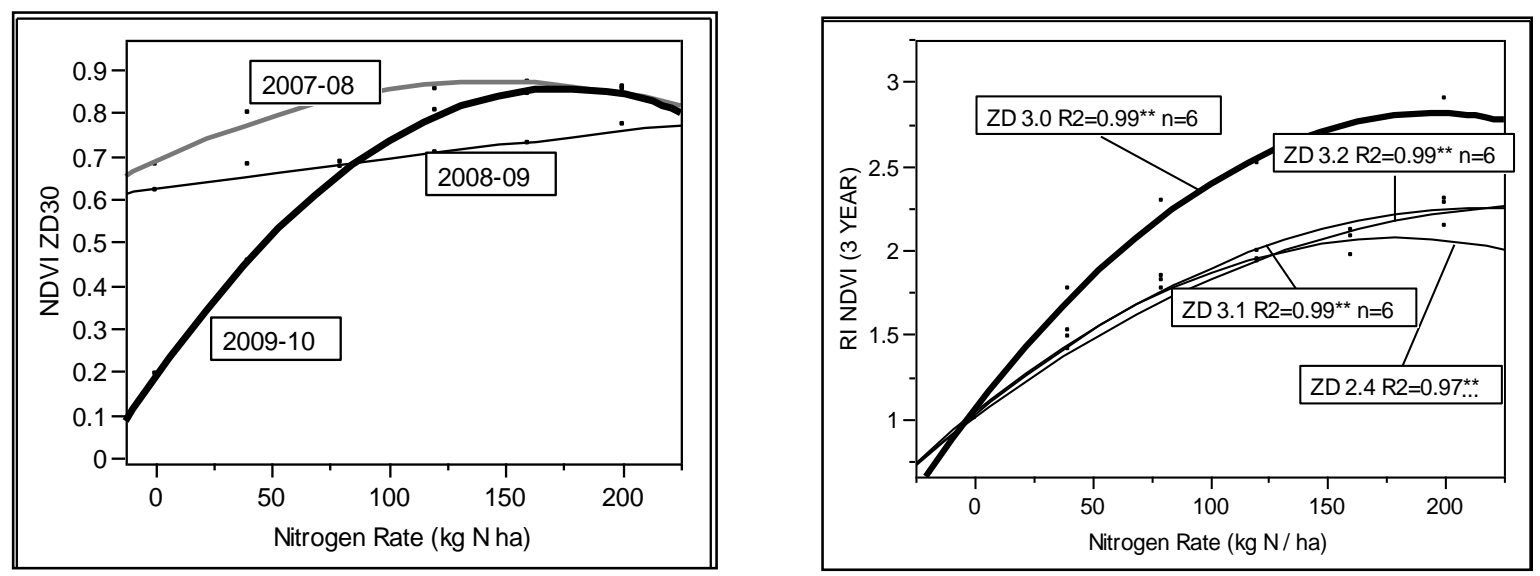

Figure 1. Effect of $\mathbf{N}$ fertilization on NDVI and RI NDVI of irrigated winter wheat in 3 different years as averaged over 4 cultivars.

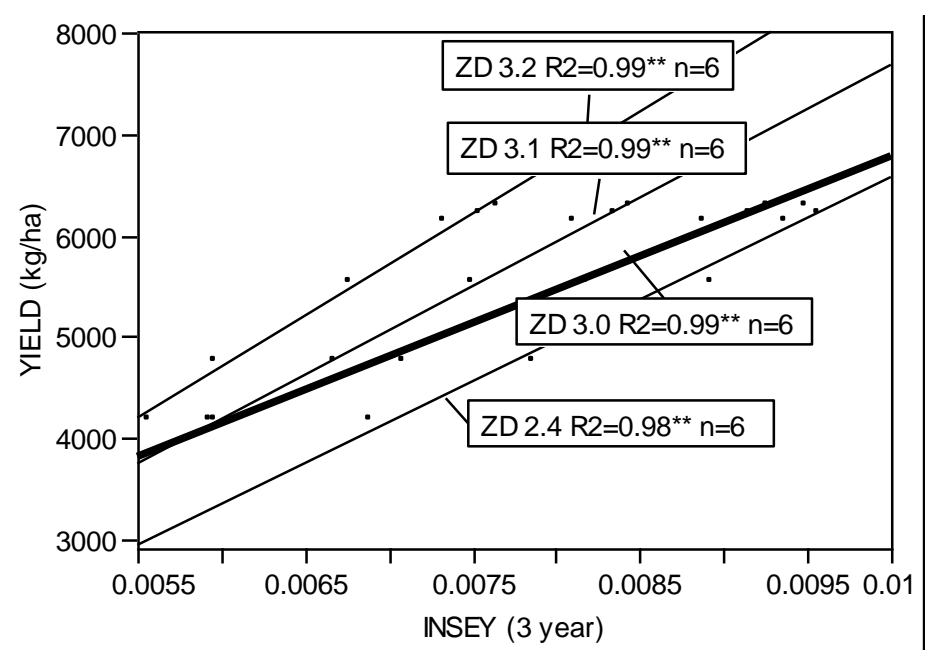

Figure 2. Regression lines of grain yield over INSEY in 3 different years.

\section{Conclusions}

Calibration equations required for the optic-sensor-based in-season nitrogen management system for irrigated wheat farming in Central Anatolia were investigated. Promising results were obtained on its applicability in 
preliminary tests conducted at farmer fields. Sufficient data were obtained to initiate an improved nitrogen fertilizer recommendation system compared to those reported by presently used methods. The results indicated that yield potential in wheat could be predicted in season with INSEY measured with the optic sensor.

Optic sensor readings were performed at four different growth stages. The Zadoks 30 stage (pseudo stem elongation) was considered to be the most suitable time for readings and recommendations. Similar yield levels were obtained in the preliminary tests conducted on 6 farmer fields by $13.2 \mathrm{~kg}$ Nitrogen ha ${ }^{-1}$ less nitrogen than farmer applications. The lower rate of $\mathrm{N}$ shows the economic benefits of the new system proposed.

\section{Acknowledgements}

This study was funded by TÜBITAK-KAMAG with a grant number of 106G111. Thanks are extended to Ministry of Agriculture and Forestry and General Directorate of Agricultural Researches.

\section{Conflict of interest}

None to declare.

\section{References}

Abedi T, A Alemzadeh and SA Kazemeini, 2011. Wheat yield and grain protein response to nitrogen amount and timing. Aust. J. Crop Sci., 5: 330-336.

Aparicio N, D Villegas, J Casadesu's, JL Araus and C Royo, 2000. Spectral vegetation indices as nondestructive tools for determining durum wheat yield. Agron. J., 92: 83-91.

Andrews B, 2011. Rising fertilizer costs raising interest in newer technology for Canada. Top Crop Manager.http://www.agannex.com/spraying/rising-fertilizer-costsraising-interest-in-newer-technology-forcanada

Baral BR and P Adhikari, 2015. Use of optical sensor for in-season nitrogen management and grain yield prediction in maize. Journal of Maize Research and Development, 1: 64-70.

Baethgen WE and MM Alley, 1989. Optimizing soil and fertilizer nitrogen use by intensively managed winter wheat: II. Critical levels and optimum rates of nitrogen fertilizer. Agron. J., 81:120-125.

Bijay-Singh, RK Sharma, Jaspreet-Kaur, ML Jat, KL Martin, Yadvinder-Singh, Varinderpal-Singh, P Chandna, OP Choudhary, RK Gupta, HS Thind, Jagmohan-Singh, HS Uppal, HS Khurana, Ajay-Kumar, RK Uppal, M Vashistha, WR Raun and R Gupta, 2011. Assessment of the nitrogen management strategy using an optical sensor for irrigated wheat. Agron. Sustain. Dev., 31: 589-603.

Bremner JM, 1965. Nitrogen Ed.: C.A. Black. In: Method of Soil Analysis. Part:II. Chemical and Microbiological Properties. Agronomy Series. No: 9. Agron. Inc. Madison. Wisconsin. USA

Bushong JT, JL Mullock, DB Arnall and WR Raun, 2018. Effect of nitrogen fertilizer source on corn (Zea mays L.) optical sensor response index values in a rain-fed environment . J. Plant Nutr., 41: 1172-1183.

Christoph, W Zecha, Gerassimos, G Peteinatos, J Link and W Claupein, 2018. Utilisation of ground and airborne optical sensors for nitrogen level identification and yield prediction in wheat. Agriculture, 8: 79.

Flowers M, R Weisz and R Heiniger, 2003. Quantitative approaches for using infrared photography for assessing in-season nitrogen status in winter wheat. Agron. J., 95: 1189-1199.

Heilman JL and MR Kress, 1987. Effect of vegetation on spectral irradiance at the soil surface. Agron. J., 79: 765-768

Huete AR, RD Jackson and DF Post, 1985. Spectral response of a plant canopy with different soil backgrounds. Remote Sens. Environ., 17: 37-57.

JMP. 13.0.0. Scintilla - Copyright (C) 1998-2014 by Neil Hodgson;neilh@ scintilla.org SAS Institute. JMP 13.0 Users Guide. Carry, NC: Release SAS Institute Inc

Johnson GV and WR Raun, 2003. Nitrogen response index as a guide to fertilizer management. J. Plant Nutr., 26: 249-262.

Li F, Y Miao, F Zhang, Z Cui, R Li, X Chen, H Zhang, J Schroder, WR Raun and L Jia, 2009. In-season optical sensing improves nitrogen-use efficiency for winter wheat. Soil Sci. Soc. Am. J., 73:1566-1574.

Lukina EV, WR Raun, ML Stone, JB Solie, GV Johnson, HL Lees, JM LaRuffa and SB Phillips, 2000. Effect of row spacing growth stage, and nitrogen rate on spectral irradiance in winter wheat. J. Plant Nutr., 23: 103122.

Melaj MA, HE Echeverria, SC Lopez, G Studdert, F Andrade and NO Barbaro, 2003. Timing of nitrogen fertilization in wheat under conventional and no-tillage systems. Agron. J., 95:1525-1531.

Mullen RW, KW Freeman, WR Raun, GV Johnson, ML Stone and JB Solie, 2003. Identifying an in-season response index and the potential to increase wheat yield with nitrogen. Agron. J., 95: 347-351. 
Naser MA, 2012. Active sensing: an innovatıve tool for evaluatıng grain yield and nitrogen use efficiency of multiple wheat genotypes Advisor: Rajiv Khosla Department of Soil and Crop Sciences, Master Thesis Colorado State University Colorado (Degree of Master of Science).

Walsh O, 2015. Nitrogen Management in Field Crops with Reference Strips and Crop Sensors University of Idaho extension Bul. 896.

Walsh O, S Shafian and RJ Christiaens, 2018. Evaluation of Sensor-Based Nitrogen Rates and Sources in Wheat. International Journal of Agronomy Volume 2018 Hindawi 5670479.

Ortı-monasterio RJI and WR Raun, 2007. Reduced nitrogen and improved farm income for irrigated spring wheat in the Yaqui Valley, Mexico, using sensor based nitrogen management. J. Agric. Sci., 145: 215-222.

Raun WR, JB Solie, GV Johnson, ML Stone, RW Mullen, KW Freeman, WE Thomason and EV Lukina, 2002. Improving nitrogen use efficiency in cereal grain production with optical sensing and variable rate application. Agron. J., 94: 815-820.

Raun WR, JB Solie, ML Stone, KL Martin, KW Freeman, RW Mullen, H Zhang, JS Schepers and GV Johnson, 2005. Optical Sensor Based Algorithm for Crop Nitrogen Fertilization. Commun. Soil Sci. Plant Anal., 36: 2759-2781.

Tagarakis AC and QM Ketterings, 2017. In-Season Estimation of Corn Yield Potential Using Proximal Sensing. Agron. J., 109: 1323-1330.

Tubaña BS, DB Arnall, O Walsh, B Chung, JB Solie, K Girma and WR Raun, 2008. Adjusting midseason nitrogen rate using a sensor-based optimization algorithm to increase use efficiency in corn (Zea mays L.). J. Plant Nutr., 31: 1393-1419.

Weisz R, CR Crozier and RW Heiniger, 2001. Optimizing nitrogen application timing in no-till soft red winter wheat. Agron. J., 93: 435-442.

Zadoks JC, TT Chang and CF Konzak, 1974. A decimal code for the growth stages of cereals. Weed Res., 14: 415-421. 